\title{
АКТУАЛЬНЫЕ ПРОБЛЕМЫ СУДЕБНОГО СЛЕДСТВИЯ В СУДЕ ПРИСЯЖНЫХ И ПОДХОДЫ К ИХ РАЗРЕШЕНИЮ
}

Аннотация: В статье исследуются проблемы судебного следствия в суде присяжных и подходы к их разрешению в судебной практике. В статье рассмотрена проблема «предварительного» допроса свидетелей и специалистов, не допрошенных ранее на стадии предварительного расследования, о вызове которых в судебное заседание ходатайствуют стороны. Такой допрос производится без участия присяжных заседателей, и он не регламентирован УПК РФ. Данные о личности подсудимого, потерпевшего и свидетелей не исследуются с участием присяжных, если эти сведения не позволяют установить признаки преступления, вменяемого подсудимому. Существует необходимость корректировки сложившейся практики по этому вопросу, с учетом позиции Европейского Суда по правам человека. В суде присяжных возникают сложности с исследованием "шокирующих» доказательств - вещественных доказательств, фотографий и т.п., способных оказать на присяжных заседателей чрезмерное эмоциональное воздействие и сформировать негативное отношение $к$ подсудимому до вынесения в отношении него вердикта. Верховный Суд РФ выработал ряд критериев приемлемости исследования таких сведений с участием присяжных заседателей. Если указанные доказательства имеют существенное значение для установления обстоятельств дела, доказанность которых определяется присяжными заседателями, исследование их с участием присяжных заседателей признается правомерным. Изучение подходов к решению проблем судебного следствия в суде присяжных свидетельствует о необходимости совершенствования действующего законодательства в целях оптимизации производства в современном российском суде присяжных.

Ключевые слова: судебное следствие, суд присяжных, предварительный допрос свидетеля, присяжные заседатели, сведения о подсудимом, сведения о свидетелях, воздействие на присяжных, компетенция присяжных, шокирующие доказательства, доказательство DOI: 10.7256/1994-1471.2014.6.11499

$\mathrm{C}$ реди проблем производства в суде с участием присяжных заседателей особую слетроту приобретают проблемы судебного следствия, поскольку именно на этом этапе судебного разбирательства производится исследование всех доказательств, производится большая часть процессуальных действий, закладываются основы внутреннего убеждения присяжных заседателей.

Один из таких вопросов порождает возникшее в судебной практике обыкновение производства в судебном следствии т.н. «предварительного» допроса свидетелей и специалистов, не допрошенных ранее на стадии предварительного расследования, о вызове которых в судебное заседание ходатайствуют стороны. На время этого предварительного допроса присяжные заседатели удаляются председательствующим судьей из зала судебного заседания. Допрос этот является предварительным, поскольку лишь после этого допроса председательствующий судья решает, будет ли этот свидетель допрошен в присутствии присяжных.

Насколько соответствует УПК РФ это обыкновение судебной практики?

Верховный Суд РФ в ряде своих решений сформулировал категоричную позицию о законности предварительного допроса, несмотря на отсутствие в УПК РФ норм, прямо регулирующих эту процедуру.

Во-первых, в решениях Верховного Суда РФ отвергается позиция авторов жалоб о незаконности такого допроса, поскольку он не предусмотрен УПК РФ. Так, в кассационном определении по делу К. Судебная коллегия оценила довод жалобы о том, что «...свидетели защиты допрашивались вначале в отсутствие присяжных заседателей, а затем в их присутствии, что не предусмотрено действующим УПК РФ», следующим образом: «С учетом особенностей судебного следствия в суде с участием при-

(C) Насонов Сергей Александрович

Кандидат юридических наук, доцент кафедры уголовно-процессуального права, Московский государственный юридический университет имени О.Е.Кутафина (МГЮА)

[sergei-nasonov@narod.ru]

123995, Россия, г. Москва, ул. Садовая-Кудринская, д. 9. 
сяжных заседателей, указанных в статье 335 УПК РФ, председательствующим судьей не допущено нарушения прав подсудимых тем, что допрос свидетелей, по заявленным стороной защиты ходатайствам, проводился председательствующим вначале без участия присяжных заседателей. Доводы кассационных жалоб в этой части являются несостоятельными» ${ }^{1}$.

По другому делу Верховный Суд РФ подчеркнул: «Предварительный допрос свидетеля В. в отсутствие присяжных заседателей не следует расценивать нарушением уголовно-процессуального закона. Данная процедура допроса свидетеля (вначале допрос свидетеля без присяжных заседателей, а затем с их участием) никоим образом не могла повлиять на мнение присяжных заседателей при вынесении ими... вердикта» ${ }^{2}$.

Таким образом, процедура предварительного допроса свидетелей рассматривается Верховным Судом РФ как объективно обусловленная особенностями судебного следствия, закрепленными в статье 335 УПК РФ, т.е. имеющая нормативное основание.

Во-вторых, Верховный Суд РФ в ряде решений обозначил правовые основания производства предварительного допроса в суде присяжных.

Одним из таких оснований является необходимость проверки допустимости показаний ранее не допрошенного свидетеля: «...председательствующий правильно разрешал проводить сторонам сначала в отсутствие присяжных заседателей, поскольку данные вопросы касаются допустимости доказательств, что в соответствии с требованиями ст. ст. 334, 335 ч. 6 УПК РФ разрешаются председательствующим единолично, не относится к полномочиям присяжных заседателей и рассматриваются в их отсутствие» ${ }^{3}$. На наш взгляд, данное основание производства предварительного допроса является юридически несостоятельным, поскольку если показания свидетеля касаются допустимости доказательств, он вообще не может быть допрошен с участием присяжных, даже после допроса в их отсутствие 4 . Кроме того, вряд ли может возникнуть сомнение в до-

Кассационное определение Судебной коллегии по уголовным делам Верховного Суда РФ от 25 апреля 2012 г. № 51-О12-15сп // СПС КонсультантПлюс.

Кассационное определение Судебной коллегии по уголовным делам Верховного Суда РФ от 22 июня 2011 г. № 56-О11-52сп // СПС КонсультантПлюс.

Кассационное определение Судебной коллегии по уголовным делам Верховного Суда РФ от 01 ноября 2012 г. № 41-О12-71сп // СПС КонсультантПлюс.

4 Пашин С.А. Доказательства в российском уголовном процессе // Состязательное правосудие. Тр. науч. практ. лаб. Вып. 1. Ч. 2. М., 1996. С. 381. пустимости доказательства, применительно к показаниям еще не допрошенного свидетеля, что исключает возможность производства допроса без участия присяжных заседателей по этому основанию.

Гораздо более аргументированным представляется другой подход Верховного Суда РФ к определению основания производства предварительного допроса: «Учитывая, что производство в суде с присяжными заседателями ведется с учетом особенностей, предусмотренных главой 42, а согласно ч. 7 ст. 335 УПК РФ в ходе судебного следствия в присутствии присяжных заседателей исследуются только те фактические обстоятельства уголовного дела, доказанность которых устанавливается присяжными заседателями в соответствии с их полномочиями, предусмотренными ст. 334 УПК РФ, то председательствующий, в отсутствие присяжных заседателей обоснованно выяснял у свидетелей сведения, которые они желали довести до присяжных, и решал вопросы об относимости этих сведений к разрешению вопросов, отнесенных к компетенции присяжных. В последующем свидетели, показания которых относились к выяснению вопросов, относящихся к компетенции присяжных заседателей, были допрошены в их присутствии» ${ }^{5}$.

Таким образом, единственным, юридически состоятельным основанием производства предварительного допроса свидетелей в суде присяжных является необходимость «выяснения относимости» их показаний к вопросам, разрешение которых входят в компетенцию присяжных заседателей.

С одной стороны, такое основание соотносится с особенностями производства в суде присяжных, поскольку предварительный допрос служит процессуальным механизмом, обеспечивающим ограждение присяжных заседателей от получения сведений, не имеющих отношения к рассматриваемому делу. Очевидно, что председательствующий не всегда в состоянии своевременно отреагировать на сообщение свидетелем присяжным сведений, не относящихся к делу, а негативный эффект этого может проявиться в неправосудном вердикте присяжных заседателей. С другой стороны, отсутствие законодательной регламентации предварительного допроса свидетелей в суде присяжных создает опасность избирательного применения этой процедуры в дискриминационном формате (на практике часто предварительному допросу подвергаются именно

Кассационное определение Судебной коллегии по уголовным делам Верховного Суда РФ от 20 июля 2011 г. № 83-О11-19сп // СПС КонсультантПлюс. 
дополнительные свидетели стороны защиты, а не стороны обвинения).

Именно поэтому предварительный допрос свидетелей в суде присяжных, активно применяемый на практике, на наш взгляд, нуждается в скорейшей законодательной регламентации, что позволит оптимизировать производство в суде присяжных.

Острой проблемой в судебном следствии в суде присяжных остается исследование сведений о личности подсудимого с участием присяжных заседателей.

Согласно ч. 8 ст. 335 УПК РФ данные о личности подсудимого исследуются с участием присяжных только в той мере, в какой они необходимы для установления отдельных признаков состава преступления.

В практике Верховного Суда РФ исследование данных о личности подсудимого с участием присяжных заседателей признавалось законным, если эти сведения позволяли установить:

- отдельные признаки субъекта преступления (специальный навык): «...данные о том, что Кузнецов Р.Н. служил в спецназе в «горячей точке», могущие служить косвенным доказательством владения осужденным навыками применения огнестрельного оружия и наличия в связи с этим у него возможности совершить посягательство на жизнь потерпевших с применением оружия...могли быть исследованы в судебном заседании» 6 .

- м мотив содеянного: «... за два дня до покушения на убийство С., между Астаниным и его супругой произошел скандал, в результате которого супруга, собрав свои личные вещи, со своим малолетним ребенком переехала на постоянное место жительство к своим родителям С. и С. Астанин П.М., полагая, что причиной их семейного конфликта является тесть, испытывая к нему неприязнь, решил совершить его убийство с особой жестокостью, общеопасным способом путем сожжения» ${ }^{7}$.

С другой стороны, если с участием присяжных заседателей были исследованы данные о личности подсудимого, не имеющие указанного выше значения, это признается нарушением уголовно-процессуального закона. В кассационном определении Верховного Суда РФ по делу М. и др., в качестве основания к отмене

\footnotetext{
6 Кассационное определение Судебной коллегии по уголовным делам Верховного Суда РФ от 11 июня 2013 г. № 67-О13-36СП //СПС КонсультантПлюс.

Определение Судебной коллегии по уголовным делам Верховного Суда РФ от 03 июня 2010 г. № 14-О1025сп // СПС КонсультантПлюс.
}

приговора указывалось на следующее обстоятельство: «В ходе допроса подсудимого М.Д. адвокаты подробно выяснили характеризующие его данные (обучение в высших учебных заведениях, намерения поступить на учебу в аспирантуру и на работу в правоохранительные органы, семейное положение, отношение к военной службе)» ${ }^{8}$.

Положения части 8 ст. 335 УПК РФ, запрещающие исследовать до вынесения вердикта факты прежней судимости, признания подсудимого хроническим алкоголиком или наркоманом, а также иные данные, способные вызвать предубеждение присяжных в отношении подсудимого, не содержат безусловного запрета на исследование этих сведений с участием присяжных заседателей.

Верховный Суд РФ допускает возможность исследования сведений о предыдущей судимости подсудимого, если эти данные позволяют установить отдельные признаки состава преступления, вменяемого подсудимому.

По делу С. в кассационном определении подчеркивалось: «Судебная коллегия считает, что, учитывая конкретные обстоятельства данного уголовного дела, председательствующий обоснованно разрешил стороне обвинения исследовать в присутствии присяжных заседателей факт прежней судимости Ч. и обстоятельства, связанные с отысканием наркотических средств в его кладовой комнате. Эти обстоятельства напрямую связаны с мотивом убийства потерпевшей С. Мотив убийства - фактические обстоятельства, которые находятся на разрешении в компетенции присяжных заседателей, о чем указано в ч. 1 ст. 334 УПК РФ»9.

По другому делу Верховный Суд РФ, признав законным исследование таких сведений с участием присяжных, отметил следующее: «В присутствии присяжных заседателей сведения о предыдущей судимости Соина М.В. исследовались лишь в той степени, в какой это было необходимо для выяснения фактических обстоятельств совершенных подсудимыми преступлений: обида Соина М.В. на потерпевшего К. из-за того, что последний якобы оговорил его, способствовав этим его предыдущему осуждению, стала поводом для конфликта, приведшего к убийству ${ }^{10}$.

\footnotetext{
8 Определение Судебной коллегии по уголовным делам Верховного Суда РФ от 25 июня 2009 г. № 1-033/08 // СПС КонсультантПлюс.
}

9 Кассационное определение Судебной коллегии по уголовным делам Верховного Суда РФ от 11 мая 2005 г. № 93-о05-5сп //СПС КонсультантПлюс.

10 Апелляционное определение Судебной коллегии по уголовным делам Верховного Суда РФ от 09 июля 2013 г. № 32-АПУ13-7сп // СПС КонсультантПлюс. 
В практике Верховного Суда РФ продолжает проявляться подход, состоящий в том, что своим своевременным обращением к присяжным заседателям с разъяснением председательствующий способен устранить практически любое нарушение уголовно-процессуального закона, допущенное в судебном разбирательстве. Косвенно такой подход приводит к расширению допустимых пределов исследования данных о личности подсудимого с участием присяжных заседателей.

Иллюстрацией этого может служить следующий вывод Верховного Суда РФ по делу Н.,Ж. и Г.: «Как видно из протокола судебного заседания, председательствующий устранял от исследования такие данные о личности, которые не подлежали исследованию в присутствии присяжных. Так, когда подсудимый Женевский пытался обсуждать сведения о судимости соучастников преступления, председательствующий судья разъяснил недопустимость этого, обратил внимание присяжных на то, что они не должны учитывать указанные доводы подсудимого» ${ }^{11}$.

В случае доведения до присяжных заседателей единичных и неконкретизированных сведений о личности подсудимого, это не признается существенным нарушением уголовнопроцессуального закона ${ }^{12}$.

Особенную остроту в судебной практике приобрела проблема исследования с участием присяжных заседателей сведений, характеризующих личность свидетелей и потерпевших по делу.

УПК РФ не содержит специальной нормы, регламентирующей исследование в первой части судебного следствия (с участием присяжных заседателей) данных о личности свидетелей и потерпевших.

Вместе с тем положения ч.8 ст. 335 УПК РФ в судебной практике толкуются таким образом, что, по общему правилу, исследование подобных сведений с участием присяжных заседателей запрещается.

В Определении Конституционного Суда РФ по этому поводу отмечается, что положения ч. 8 ст. 335 УПК «...не регламентируют вопросы исследования в присутствии присяжных заседателей сведений о личности потерпевшего и свидетеля. Такие вопросы с учетом необходимости сохранения судом объективности и беспристрастности в ходе судебного разбиратель-

11 Кассационное определение Судебной коллегии по уголовным делам Верховного Суда РФ от 4 марта 2004 г. № 9-о04-7сп // СПС КонсультантПлюс.

12 Апелляционное определение Судебной коллегии по уголовным делам Верховного Суда РФ от 04 апреля 2013 г. № 6-АПУ13-2сп // СПС КонсультантПлюс. ства разрешаются на основе взаимосвязанных положений статей 252, 299, 334 и 335 (части третья, шестая и седьмая) УПК Российской Федерации, в соответствии с которыми в присутствии присяжных заседателей не подлежат исследованию вопросы права, не входящие в компетенцию присяжных и способные вызвать их предубеждение в отношении участников процесса» ${ }^{13}$.

В судебной практике Верховного Суда РФ положения части 8 комментируемой статьи распространены на исследование аналогичных сведений в отношении свидетелей и потерпевших ${ }^{14}$.

Отменяя оправдательный приговор по делу А., Верховный Суд РФ указал: «В нарушение закона в ходе допроса свидетеля Аскольской стороной защиты выяснялись данные о личности свидетеля Меркушевой. Но, несмотря на это председательствующий, как видно из протокола судебного заседания, замечание стороне защиты не сделал» ${ }^{15}$.

Обоснованием такой позиции Верховного Суда РФ чаще всего служит указание на то, что исследование указанных сведений противоречит положениям части 7 комментируемой статьи, поскольку присяжные заседатели не уполномочены устанавливать своим вердиктом указанные обстоятельства ${ }^{16}$.

Верховный Суд РФ аргументирует свой подход также опасностью нарушения ч.1 ст. 252 УПК РФ в случае исследования негативных данных о личности потерпевших и свидетелей ${ }^{17}$.

Аналогичная аргументация используется и в случаях, когда сторона защиты выясняет возможность причастности свидетеля (потерпевшего) к преступлению, вменяемому подсудимому ${ }^{18}$.

В научной литературе указанные подходы Верховного Суда РФ признаются верными. Так, по мнению Т. Владыкиной, исследование подобных сведений с участием присяжных засе-

13 Определение Конституционного Суда РФ от 11 мая 2012 г. № 686-О //СПС КонсультантПлюс.

14 Определение Военной коллегии Верховного Суда РФ от 30 ноября 2006 г. № 1-50/2005 // СПС КонсультантПлюс.

15 Бюллетень Верховного Суда РФ. 2005. № 8. С. 23, 26-28.

16 Кассационное определение Судебной коллегии по уголовным делам Верховного Суда РФ от 23.03.2011 № 25-О11-4СП //СПС КонсультантПлюс.

17 Кассационное определение Судебной коллегии по уголовным делам Верховного Суда РФ от 10 августа 2005 г. № 67-о05-50сп // СПС КонсультантПлюс.

18 Кассационное определение Судебной коллегии по уголовным делам Верховного Суда РФ от 5 марта 2003 г. № 4-кпо03-13сп // СПС КонсультантПлюс. 
дателей не входит в компетенцию присяжных заседателей и способно вызвать их предубеждение в отношении участников процесса ${ }^{19}$.

T. Моисеева полагает, что данные, характеризующие личность потерпевшего или свидетеля, не должны приводиться для доказательства виновности или невиновности подсудимого, однако, они могут исследоваться «...лишь в той мере, в какой необходимы для установления отдельных признаков состава преступления, в совершении которого обвиняется подсудимый» ${ }^{20}$.

Между тем в постановлении Европейского Суда по правам человека по делу «Пичугин против Российской Федерации» 23 октября 2012 г. содержится иной подход к допустимости исследования данных о личности свидетелей и потерпевших с участием присяжных заседателей.

Европейский Суд отметил в указанном решении, что «...положение Заявителя было... усугублено тем, что ему не было позволено задавать г-ну К. вопросы об определённых факторах, способных подорвать достоверность его показаний», «... председательствующий судья сняла все вопросы о судимостях г-на К., о том, почему он не давал инкриминирующих Заявителя показаний в ходе своих первых допросов в 1999 г. и о том, что именно мотивировало его начать давать такие показания в 2003 г., а также вопросы, касающиеся возможно оказанного на него давления со стороны органов прокуратуры» ${ }^{21}$.

Указав на то, что показания свидетеля К. были решающими для осуждения подсудимого, Европейский Суд отметил, что указанные вопросы свидетелю со стороны защиты были крайне важны, поскольку позволяли оспорить достоверность его показаний, оценка которых отнесена к исключительной компетенции коллегии присяжных заседателей: «Задачей коллегии присяжных было определить, какое значение (если вообще они имеют какое-либо значение) следует придавать показаниям г-на К. против Заявителя. С тем, чтобы эту задачу выполнить, присяжным должны были быть известны все имеющие к делу обстоятельства, влияющие на точность и достоверность данных показаний, включая какие-либо возможно

19 Владыкина Т. Особенности судебного следствия в суде с участием присяжных заседателей // Уголовное право. 2013. № 2. С. 86.

20 Моисеева Т. Особенности судебного следствия в суде с участием присяжных заседателей: анализ практики Верховного Суда РФ // Уголовное право. 2012. № 1. C. 97.

21 Постановление ЕСПЧ по делу «Пичугин против Российской Федерации» 23 октября 2012 г. (жалоба № 38623/03), п.п. 206, 210 //СПС КонсультантПлюс. имевшиеся у г-на К. побудительные причины ложного изложения фактов. Соответственно, защите было важно обсудить вышеуказанные вопросы в присутствии коллегии присяжных с тем, чтобы проверить достоверность и правдивость показаний г-на К. Суд озабочен заявлением председательствующей судьи, что Защите Заявителя «не разрешается подвергать показания свидетеля сомнению»... и что коллегии присяжных "нет необходимости знать, что мотивировало (г-на К.) дать показания против Заявителя"» ${ }^{22}$.

В итоге, Европейский Суд пришел к выводу, что запрет исследования данных о личности потерпевшего с участием присяжных заседателей в данном случае «...права Заявителя на защиту были ограничены в объёме, несовместимом с предоставляемыми ст. $6 \S 1$ и 3 (d) Конвенции гарантиями» ${ }^{23}$, что нарушило его право на справедливое судебное разбирательство.

Очевидно, что российская правоприменительная практика в вопросе о возможности исследования данных о личности свидетеля и потерпевшего в присутствии присяжных заседателей должна быть скорректирована с учетом указанной позиции Европейского Суда по правам человека.

Представляет интерес специфика исследования некоторых доказательств в судебном следствии с участием присяжных заседателей.

В практике Верховного Суда РФ сформировался подход о неприемлемости исследования с участием присяжных заседателей заключения психофизиологической экспертизы обвиняемого (исследование на полиграфе) ${ }^{24}$. Позиция Верховного Суда о запрете исследования этого доказательства с участием присяжных заседателей основана на том, что это заключение «не является доказательством факта» и вследствие этого не должно оцениваться присяжными заседателями ${ }^{25}$.

В судебной практике признается правомерным отказ от исследования с участием присяжных исследовательской части заключения эксперта, если она изобилует специальной терминологией, уяснение которой затруднительно для присяжных заседателей ${ }^{26}$.

\section{2 Там же, п. 210. \\ 23 Там же, п. 212.}

24 Кассационное определение Судебной коллегии по уголовным делам Верховного Суда РФ от 06 июня 2012 г. № 19-О12-13сп // СПС КонсультантПлюс.

25 Кассационное определение Судебной коллегии по уголовным делам Верховного Суда РФ от 05 мая 2011 г. № 41-О11-43сп // СПС КонсультантПлюс.

26 Кассационное определение Судебной коллегии по уголовным делам Верховного Суда РФ от 10 августа 2005 г. № 58-о05-33сп // СПС КонсультантПлюс. 
Продолжает сохранять актуальность и проблема исследования с участием присяжных т.н. «шокирующих» доказательств - вещественных доказательств, фотографий и т.п., способных оказать на присяжных заседателей чрезмерное эмоциональное воздействие и сформировать негативное отношение к подсудимому до вынесения в отношении него вердикта ${ }^{27}$.

Верховный Суд РФ в отдельных случаях признает правомерным отказ председательствующего в исследовании таких доказательств с участием присяжных заседателей, если они не имеют особого доказательственного значения, однако они могут вызвать предубеждение у присяжных: «Отказывая в обозрении присяжными заседателями фототаблицы осмотра трупов К. и Т., суд обоснованно указал, что они не могут быть представлены присяжным, так как трупы сфотографированы после их вскрытия и на них не видны повреждения. Кроме того, внешний вид вскрытых трупов может оказать на присяжных эмоциональное воздействие и повлиять на принятие ими объективного решения» ${ }^{28}$.

Принимая решение о правомерности исследования подобных доказательств с участием присяжных заседателей, Верховный Суд оценивает - могло ли их содержание негативно повлиять на присяжных заседателей и в ряде случаев приходит к категоричному выводу об отсутствии такого воздействия: «На оспариваемых осужденным фототаблицах... зафиксирована обстановка места происшествия и нет таких сведений, которые могли негативно воздействовать на присяжных заседателей» ${ }^{29}$.

Верховный Суд РФ, как правило, не распространяет концепцию «шокирующих доказательств» на доказательства, не содержащие изображение или видеозапись, полагая, что степень воздействия подобных сведений не влечет негативного воздействия на присяжных заседателей ${ }^{30}$.

Кроме того, Верховный Суд РФ не признает исследованные с участием присяжных доказательства, способными вызвать у них предубеждение, если метод такого исследования обеспечил нейтрализацию возможного негативного эмоционального воздействия. Этот метод может состоять в предъявлении указанных доказательств присяжным заседателям фрагментарно: «Из протокола судебного заседания следует, что государственный обвинитель представил на обозрение коллегии присяжных заседателей фототаблицу к протоколу осмотра места происшествия без демонстрации трупа $M .{ }^{31}$.

Верховный Суд РФ, решая вопрос о том, оказало ли на присяжных негативное эмоциональное воздействие исследование с их участием «протокола осмотра автомашины с обгоревшими трупами» с приложением фототаблицы, проанализировал цвет и размер изображения на этих фотографиях ${ }^{32}$.

Вместе с тем, если указанные доказательства имеют существенное значение для установления обстоятельств дела, доказанность которых определяется присяжными заседателями, исследование их с участием присяжных заседателей признается правомерным ${ }^{33}$.

Таким образом, необходимо законодательно закрепить условия исследования указанных доказательств с участием присяжных, на основе подходов, сформировавшихся в судебной практике.

Изучение подходов к решению проблем судебного следствия в суде присяжных свидетельствует о необходимости совершенствования действующего уголовно-процессуального законодательства в целях оптимизации производства в современном российском суде присяжных.

\section{Библиография:}

1. Владыкина Т. Особенности судебного следствия в суде с участием присяжных заседателей // Уголовное право. 2013. № 2. С. 84-92.

27 Насонов С.А. Судебное следствие в суде присяжных: законодательство, теория и практика. Научно-практическое пособие. М.: Р. Валент, 2001. С.173-179.

28 Определение Судебной коллегии по уголовным делам Верховного Суда РФ от 01 ноября 2006 г. № 41-о0667сп // СПС КонсультантПлюс.

29 Апелляционное определение Судебной коллегии по уголовным делам Верховного Суда РФ от 24 июля 2013 г. № 41-АПУ13-23сп // СПС КонсультантПлюс.
30 Обзор судебной практики ВС РФ «Обзор кассационной практики Судебной коллегии по уголовным делам Верховного Суда РФ за 2004 год» // СПС КонсультантПлюс.

31 Апелляционное определение Судебной коллегии по уголовным делам Верховного Суда РФ от 29 июля 2013 г. № 20-АПУ13-18сп // СПС КонсультантПлюс.

32 Кассационное определение Судебной коллегии по уголовным делам Верховного Суда РФ от 24 мая 2011 г. № 56-О11-41сп // СПС КонсультантПлюс.

33 Определение Судебной коллегии по уголовным делам Верховного Суда РФ от 26 июня 2008 г. № 41-00842 сп // СПС КонсультантПлюс. 
2. Моисеева Т. Особенности судебного следствия в суде с участием присяжных заседателей: анализ практики Верховного Суда РФ // Уголовное право. 2012. № 1. - С.95-99.

3. Насонов С.А. Судебное следствие в суде присяжных: законодательство, теория и практика. Научно-практическое пособие. М.: Р.Валент, 2001. - 190 с.

4. Пашин С.А. Доказательства в российском уголовном процессе // Состязательное правосудие. Тр. науч. - практ. лаб. Вып. 1. Ч. 2. М., 1996. - С. 311-390.

\section{References:}

1. Vladykina T. Osobennosti sudebnogo sledstviya v sude s uchastiem prisyazhnykh zasedatelei // Ugolovnoe pravo. 2013. № 2. S. 84-92.

2. Moiseeva T. Osobennosti sudebnogo sledstviya v sude s uchastiem prisyazhnykh zasedatelei: analiz praktiki Verkhovnogo Suda RF // Ugolovnoe pravo. 2012. № 1. - S.95-99.

3. Nasonov S.A. Sudebnoe sledstvie v sude prisyazhnykh: zakonodatel'stvo, teoriya i praktika. Nauchno-prakticheskoe posobie. M.: R.Valent, 2001. - 190 s.

4. Pashin S.A. Dokazatel'stva v rossiiskom ugolovnom protsesse // Sostyazatel'noe pravosudie. Tr. nauch. - prakt. lab. Vyp. 1. Ch. 2. M., 1996. - S. 311-390.

Материал поступил в редакцию 18 марта 2014 г. 